How to Cite:

Jumanovich, A. T. (2021). Creation of the image of ibn sina in the east and its peculiarities. Linguistics and Culture Review, 5(S3), 104-110.

https://doi.org/10.37028/lingcure.v5nS3.1397

\title{
Creation of the Image of Ibn Sina in the East and its Peculiarities
}

\author{
Abdukhamid Tangirov Jumanovich \\ Candidate of Philological Science, Associate Professor, Jizzakh State Pedagogical \\ Institute, Jizzakh, Uzbekistan
}

\begin{abstract}
In fiction, the creation of historical reality and the character of a historical figure is a complex process in which artists create unique styles and genres for each event in the creation of a work of art. This can only be seen in the variety of colors used to create the image of the great oriental scholar Ibn Sina. In short, the creation of historical reality and the character of historical figures in works of art is a complex process, in which writers use a variety of methods and techniques not only for demands of the genre, but also for the historical reality or the place and qualities of the historical figure. This can be verified only by the peculiarities of the creation of the image of Ibn Sina.
\end{abstract}

Keywords---anochronism, epic, generalization, legend, medical science, myth, the cure for death.

\section{Introduction}

It is known from history that the sultan of the world medical science, our ancestor Abu Ali Ibn Sina was a great judge, philosopher, linguist, literary critic and astronomer, who became famous and popular during his lifetime. As a result, during his lifetime, various memoirs, legends and myths were created about him. Therefore, the works written about him are radically different and require special study (Heath, 2010; Vamberi, 1990; Donnino et al., 2007). Observations show that in all works of art, fiction and non-fiction about Ibn Sina, there are two main aspects: First, most of the works about Ibn Sina consist of memories, recollections, and impressions of the scholar. This tradition, initiated by Abu Ubayd al-Juzjani, has been preserved and perfected in all written works of the twentieth century. A.Irisov's "Abu ibn Sino", S.Ulugzoda's "Piri hakimovi mashriqzamin" ("Piri of the rulers of the East"), historical-publicist pamphlets, O.Yakubov's novel "Old world", Abdulla Aripov's "Hakim and death" epic, S. Ulugzoda's drama "Youth of Ibn Sina" and a number of other works are considered as works of this category.

Linguistics and Culture Review (c) 2021.

Corresponding author: Jumanovich A. T.; Email: ozodbekjon.nematovich@gmail.com

Manuscript submitted: 9 April 202 1, Manuscript revised: 18 June 2021, Accepted for publication: 23 July 2021 


\section{Method}

The second group is the folklore, such as the legend and narration about Ibn Sina. Dozens of popular myths and legends, such as "Ibn Sina and the Woman", "Ibn Sina and the Cure for Death", reflect the characteristics of Ibn Sina's character. Both the Tajik poet Mumin Qanoat and the Uzbek poet Abdulla Aripov skillfully use these two qualities in their epics to shape the image and character of Ibn Sina. M. Qanoat created his epic "Sino beshigi" on the basis of his memoirs about the hero of the work, his memories of what he saw and experienced, while Abdulla Aripov in the epic of "Hakim and the death" is based on folk legends and myths for creating the image of Ibn Sina. At first glance, M. Qanoat's epic "Sino beshigi" is reminiscent of a historical and biographical work about the life and work of the great scientist. In the play scientist follows a strict chronological order of dates and events related to the life and work of Ibn Sina.

The plot begins with the birth of a young child in the house of Sitorabonu in the village of Afshona, near Bukhara. One day, the Emir of Bukhara, Noah ibn Mansur, fell ill. Young Hussein treats him. In return, he will be able to enter the Emir's library and work. After the Qarakhanids conquered Bukhara, Noah Somoni was overthrown. Hussein left Bukhara with his brother Mahmud and went to Khorezm. In Khorezm, he placed as one of the scholars at the Al Mamun Palace. He works with Abu Nasir al-Iraqi, Abu Sa'id al-Masihi, and Abu Rayhan al-Biruni. He argues scientifically with them. The ruler of the Ghazna, Mahmud Ghaznawi, sent a request to Al Ma'mun to send scholars such as Ibn Sina to his service. Sensing his inability to resist, the Khorezm ruler told Ibn Sina and other scholars to go to Ghazna. Scientists deny this. Ibn Sina also secretly left Khorezm and came to Nishapur. In Nishapur, he meets and argues with Sheikh Abusaid Mayhani, one of the representatives of mysticism. Then he comes to Juzjan. He meets Juzjani and be friends him for life (Pardayeva et al., 2020; Tosh, 2003).

He went to Ray, one of the most famous states of his time. There Ibn Sina was in the presence of Queen Saida, and at her request he cured Majiduddawla, the queen's mentally retarded son. With his recovery, Majiduddawla will be succeeded by his mother. One day, during his reign, a rebellion broke out. He appealed to Mahmud Ghaznavi to quell the uprising. The Ghaznavi not only quelled the revolt, but also captured Majiduddawla himself. Ibn Sina, who did not like Mahmud Ghaznavi, left and came to Hamadan to serve King Shamsududdawla. He had cochlear disease. He cured of his illness and appointed as a minister. He works tirelessly for the prosperity of the country (Olson, 1988; Kleinman, 1978). When Shamsududdawla died and the throne passed to his son Samouddawla, Ibn Sina refused to be in his service. Then the governor of Isfahan captured Hamadon. Ibn Sina also came to Isfahan. In Isfahan, Ibn Sina created a meaningful work. Created a number of works. Mahmud Ghaznavi's son Mas'ud attacked Isfahan and blew up the ashes of Ibn Sina's library. He took many of his works to Ghazna. The plot of the work ends with the lyrical character's views on Ibn Sina's death in Hamadan.

At first glance, the plot seems to be no different from a light interpretation of historical reality. However, in the epic, the poet does not try to give a simple interpretation of these events, but tries to find the characteristics of a scientist's 
character in the background of that historical reality. For example, the epic states that Noah Somoni became seriously ill. All doctors tried to cure it. But there was no cure for this. Then they called Ibn Sina. Ibn Sina cured for the illness of the Amir. Amir asked Ibn Sina what he would get in return. Ibn Sina replied:

... "O Amir, I would be so happy

If I passed the Darwish test of the king

That's the decent thing to do, and it should end there

I have no other choice

My market for knowledge among the world's goods

Let the treasure of knowledge be what I want".

Thus, Ibn Sina entered the Amir's library and received permission to read. In this way, the reader is presented with the image of a person who values science and puts it above all else. In another episode, the poet makes major generalizations based on historical events. To prove our point, consider the following two interpretations: In his historical and piblicistic work "Abu Rayhan Beruni, Abu Ali ibn Sino" A. Kayumov explains the illness of the Amir, where he was, in what condition and how Ibn Sino visited him: "Hussein entered the house where the Amir slept with doctors when he arrived, he was suffocated by the stifling air of the house which adorned with royal ornaments, precious rugs, and royal beds. Amir lay motionless on layers of satin blankets in the net of the house, breathing heavily. Next to him, azayimkhon is doing his works. The house is full of incense". Thus the doctor begins to treat the amir. He relieves severe pain by giving various medicines. M. Qanoat, on the other hand, creates a completely generalized picture of this situation:

They brought Ibn Sino,

Young, intelligent and sage,

He saw that the crown of the patient was on his head,

He said: $\mathrm{O}$, amir forgive me and put off the crown

One patient is enough for doctor "....

... Amir fell from the head of more reluctant hatred,

For the sweet soul of him he,

Passed from the golden crown.

He made a sign and room was empty,

and the king was free from arrogance.

And he felt sick,

And he felt helpless ...

He said to the king: "If my command is smooth, it is a cure for pain, and if it is as commanded as order, it is obligatory". If the above interpretation of historical reality is a simple one for the reader, then the poetic interpretation has a deep meaning. In it, the poet gives a philosophical generalization that the king and the poor are equal before the doctor and the disease. The emir, who always tried to give orders, this time had to obey the doctor's order. The poet prefers medicine than the kingdom. 


\section{Discussion}

The epic is characterized not only by the interpretation of historical events, but also the interpretation of the lyrical hero's attitude to this historical event and the hero Ibn Sina. In doing so, the poet avoids simple narratives and makes sharp philosophical observations. For example:

You called the earth eternal, that is inevitable, You called the mind light, and the world is brighter than it, You have revealed the world of mysteries,

You have solved the mystery of death...

The poet's effective use of memories and recollections of Ibn Sina in the play also had a significant impact on the overall structure of the work. The construction of the epic is different from most epics. At first glance, the poet seems to have used the views of two heroes to achieve his goal. The first is a lyrical hero and the second is a storyteller.

In the story, the narrator, the hero Ibn Sina, continues to tell his story during the plot. Much of the story unfolds as a collection of memories of him. But this does not mean that the lyrical protagonist in the epic goes beyond the interpretation of the course of events. In the play, the lyrical protagonist often presents himself as the protagonist - the narrator, as well as the protagonist who develops the events, connects the various stories of the narrator and expresses his attitude to them. It can be said that M. Qanoat masterfully used all the possibilities of the epic genre in creating the character of Ibn Sina and was able to demonstrate his unique artistic skills. In particular, it demonstrates the richness of all the possibilities of the epic genre (Gross \& Sepkowitz, 1998; Collins, 2007).

In the epic "Sino beshigi" there are a number of episodic images of historical figures. They can also be divided into two types: The first group: Noah Somoni, Ali Mamun, Mahmud Ghaznavi, Sayida Malika, Majidudduvla, Shamsuddavla, Samouddavla, Alouddavla, Masul Ghaznavi and other emirs and heads of state. The second group: scholars, thinkers and clerics such as Beruni, Abu Nasr alIraqi, Abu Sahl al-Masihi, Abu Ubayd al-Juzjani, Sheikh Mayhani.

The poet also serves to create the episodic images of these historical figures directly to the character of the hero. This can be seen only by looking at the role of Beruni in the play. The two scholars, who first met in Khorezm, have always been in creative contact. They debated in the field of science. Therefore, it has become a tradition to interpret these two thinkers not only in historical sources, but also in fiction works. For example, in Odil Yakubov's novel "The Old World", the characters Beruni and Ibn Sino reveal each other's qualities and complement each other. The same tradition is followed in the epic "Sino beshigi", which, although episodic, uses the image of Beruni.

The image of Beruni in the epic served to reveal Ibn Sina's keen observation and strong knowledge. In doing so, the poet used the scientific debate of Ibn Sina and Beruni. Beruni raises various scientific issues. Ibn Sina, on the other hand, finds a solution to every problem in a methodical way. In this way, the poet skillfully 
reveals that Ibn Sina was a man of great knowledge (Polit \& Beck, 2010; Branchek \& Blackburn, 2003).

The image of Sheikh Abdusaid Mayhani is included in the epic to show Ibn Sina's attitude towards religion. To do this, the poet used the famous dialogue of Hakim and Sheikh. According to sources, after the meeting, the famous mystic sheikh and the great scientist of medicine "confessed to each other." Ibn Sina said to his disciples, "Abu Sa'id will feel what I understand," and Abu Sa'id said, "Ibn Sina will understand what I feel." Thus, both scholars were the first to acknowledge the equality of the mental-logical and emotional-symbolic paths in the knowledge of the material world and the spiritual world of man (Schmidt et al., 2019; Sander et al., 1990).

Unfortunately, in this dialogue and in some other places, Ibn Sina's attitude towards religion did not find its true interpretation. In some places, the great Judge is portrayed as an atheist, influenced by the years of stagnation. In the epic, Ibn Sina even argues with God and tries to expose him. However, in Aripov's epic "Judge and Death", written at the same time, Ibn Sina's attitude to religion found its true expression. The poet did not deepen this relationship (the period did not allow it - A.T.), in turn, did not falsify (does not want to distort the historical truth - A.T.). In the epic, the Judge is always afraid to blaspheme God. $\mathrm{He}$ is very careful. He sees God as the creator of all blessings. And every particle sees the opposite:

What is the purpose of creation?

At such a time, Hakim bowed with repentance,

Thou hast commanded the slaves to do the work of a slave,

You are in every particle, only you.

The judge also undoubtedly strives for the Truth. But he believes that the Truth can be attained only by overcoming the difficulties of life:

... If I had found a cure for death,

I would have solved it, 'said Hakim,' all questions.

It is obvious that not all writers were against religion during the Soviet era, and there were brave writers like A. Aripov at that time. A. Aripov took a completely different approach to the creation of the character of Abu Ali ibn Sino. He does not try to create a complete picture of Ibn Sina's work like M. Qanat. The poet is more interested in the events of Ibn Sina's medicine and his death.

Ibn Sina suffered from asphyxiation for many years and treated himself. He is self-righteous. But Hakim's illness worsened and he contracted epilepsy. "One day," says al-Juzjani, "he ordered two celery seeds to be mixed into what he was going to do (Ibn Sina - A.T.). With this he wanted to drive his inner winds. One of the doctors who was treating him sent him five dirhams of celery seeds. I don't know if he did it on purpose or wrongfully he did. The sharpness of this seed made the bowel movement worse. He was taking anti-seizure mitridate. One of the servants added more opium to mitridat and the sheikh drank it. The reason was that they had betrayed a lot of the Sheikh's property, and they were afraid of the 
consequences of their actions and therefore waited for his death (Vitchenko et al., 2021; Azizaliyeva, 2021).

Similar incidents related to the death of Ibn Sina have been interpreted differently in different sources, as well as in folklore. For example, in the legend of Ibn Sina and the cure for death, it is interpreted as follows: Abu Ali ibn Sina also found a cure for death. At the time of his death, he bequeathed medicine to one of his disciples. The medicine was in forty containers. Abu Ali ibn Sina said, "You should drip this medicine in my mouth since I died.".

After Hakim's death, the student was taking the medicine. When the thirty-ninth medicine was being given, Hakim began to open his eyes. The disciple then threw the fortieth medicine on the ground, and Hakim was not resurrected. In the epic of the "Judge and death", Abdulla Aripov creates a beautiful example of this genre of the legend.

\section{Conclusion}

In short, the creation of historical reality and the character of historical figures in works of art is a complex process, in which writers use a variety of methods and techniques not only for demands of the genre, but also for the historical reality or the place and qualities of the historical figure. This can be verified only by the peculiarities of the creation of the image of Ibn Sina.

\section{Acknowledgments}

According to historical sources, Ibn Sina made many disciples during his lifetime, made friends. But not all of these friendly disciples are faithful to him. Among them are traitors and hypocrites. One such traitor is the scholar's disciple Ibrahim from Hamadan. Ibrahim got into Ibn Sina's arms and caused him a lot of trouble. Historical sources also indicate that Ibn Sina's death was caused by the betrayal of the disciples.

\section{References}

Azizaliyeva, B. (2021). Peculiarity of the concept of a hero in the novel of Vladimir Nabokov "Lolita" Humbert. Linguistics and Culture Review, 5(S2), 28-35.

Branchek, T. A., \& Blackburn, T. P. (2003). Trace amine receptors as targets for novel therapeutics: legend, myth and fact. Current opinion in pharmacology, 3(1), 90-97. https://doi.org/10.1016/S1471-4892(02)00028-0

Collins, P. (2007). Poe's cure for death. New Scientist, 193(2586), 50-51. https://doi.org/10.1016/S0262-4079(07)60107-9

Donnino, M. W., Vega, J., Miller, J., \& Walsh, M. (2007). Myths and misconceptions of Wernicke's encephalopathy: what every emergency physician should know. Annals of emergency medicine, 50(6), 715-721. https://doi.org/10.1016/j.annemergmed.2007.02.007

Gross, C. P., \& Sepkowitz, K. A. (1998). The myth of the medical breakthrough: smallpox, vaccination, and Jenner reconsidered. International journal of infectious diseases, 3(1), 54-60. https://doi.org/10.1016/S12019712(98)90096-0 
Heath, P. (2010). Allegory and Philosophy in Avicenna (Ibn Sina). University of Pennsylvania Press.

Kleinman, A. (1978). Concepts and a model for the comparison of medical systems as cultural systems. Social Science \& Medicine. Part B: Medical Anthropology, 12, 85-93. https://doi.org/ 10.1016/0160-7987(78)90014-5

Olson, C. B. (1988). A possible cure for death. Medical hypotheses, 26(1), 77-84. https://doi.org/10.1016/0306-9877(88)90118-1

Pardayeva, K., Tangirov, A., \& Muxammadiyeva, S. (2020). The Use Of The Humanistic Ideas Of Khoja Ahmad Yassavi I + -9n The Teaching Of Pedagogical Sciences. JSPI Scientific Publications Archive.

Polit, D. F., \& Beck, C. T. (2010). Generalization in quantitative and qualitative research: Myths and strategies. International journal of nursing studies, 47(11), 1451-1458. https://doi.org/10.1016/j.ijnurstu.2010.06.004

Sander, J. W. A. S., Hart, Y. M., Shorvon, S. D., \& Johnson, A. L. (1990). Medical science: National General Practice Study of Epilepsy: newly diagnosed epileptic seizures in a general population. The Lancet, 336(8726), 1267-1271. https://doi.org/10.1016/0140-6736(90)92959-L

Schmidt, M., Graef, C., \& Gross, D. (2019). Legend or Truth? The supposed distance of the German pathologist Maximilian Borst (1869-1946) from National Socialism. Pathology-Research and Practice, 215(5), 1076-1082. https://doi.org/10.1016/j.prp.2019.02.021

Tosh, N. (2003). Anachronism and retrospective explanation: in defence of a present-centred history of science. Studies in History and Philosophy of Science Part A, 34(3), 647-659. https://doi.org/10.1016/S0039-3681(03)00052-9

Vamberi, H. (1990). History of Bukhara or Mavorounnahr. T.: Ghafur Ghulam Publishing House of Literature and Art.

Vitchenko, A. O., Vitchenko, A. Y., Izhutova, I. V., Aleksandrova, L. G., \& Romaniuk, V. L. (2021). Activating the cognitive learning activity through "Dead" case. Linguistics and Culture Review, 5(S2), 599-607. 